\title{
Upaya Peningkatan Kualitas Daging Ayam Broiler Melalui Pemberian Ekstrak Meniran
}

\author{
Puji Astuti, Heru Suripta, dan Lusia Risyani PM¹) \\ ${ }^{1)}$ Akademi Peternakan Karanganyar \\ Email : tutiamir88@gmail.com
}

\begin{abstract}
Abstrak
Penelitian ini dilakukan untuk mengevaluasi pengaruh ekstrak meniran yang diekstraksi dengan air maupun metanol sebagai pengganti feed additive komersial untuk mengetahui pengaruhnya terhadap kualitas daging ayam broiler. Penelitian ini menggunakan broiler umur satu hari. 200 ekor broiler dikelompokkan ke dalam 4 perlakuan yaitu : 1) Kontrol, broiler diberi air minum tanpa mengandung feed additive: 2) Broiler diberi air minum yang mengandung feed additive komersial (basitrasin) sesuai dosis, 3 ) Broiler diberi air minum yang mengandung ekstrak meniran yang diekstrak dengan metanol sejumlah 40 $\mathrm{mg} / \mathrm{l}$; 4) Broiler diberi air minum mengandung ekstrak meniran yang diekstrak air sejumlah 40 mg/l air minum. Setiap perlakuan terdiri dari 5 buah kandang panggung (postal) berisi 10 ekor broiler sebagai ulangan. Pada akhir penelitian, 4 ekor broiler untuk setiap kelompok perlakuan dipotong, lemak perut, dan karkasditimbang. Variabel yang diamati meliputi performans (konsumsi pakan, pertambahan bobot badan, dan konversi pakan), karakteristik karkas (persentase karkas, rasio daging tulang, dan pesentase lemak abdominal), dan kualitas daging (kandungan lemak, kolesterol, dn asam lemak tak jenuh). Data yang terkumpul dianalisis ANOVA, data rata-rata yang berbeda diuji lanjut dengan Duncan's Multiple Range Test. Hasil penelitian menunjukkan bahwa konsumsi pakan ((84,80 vs 89,31; 89,16; 9163 g/ekor/), pertambahan bobot badan (55,87 vs 59,57; 59,34; 59,70 g/ekor/hari), karakteristik karkas, dan kualitas daging dipengaruhi ekstrak meniran. Ekstrak air memberikan kualitas daging yang lebih baik dibanding ekstrak metanol. Kesimpulan dari penelitian ini bahwa meniran yang diekstraksi dengan air lebih baik dibandingkan metanol.
\end{abstract}

Kata kunci : ayam broiler, ekstrak meniran,kualitas daging

\begin{abstract}
This research was conducted to evaluate the effects of extracts Phyllanthusniruri extracted with water and methanol as a substitute for commercial feed additive to determine the impact on the meat quality of broilers. The research use 200 broilers which were devided into four treatments and four replication: 1) Control, broilers were given drinking water without Phyllanthusniruri extract, 2) broilers were given feed additive commercially (bacitracin), 3) broilers were given methanol extract as much as $40 \mathrm{mg} / \mathrm{l}$; and 4) broilers were given water extract as much as of $40 \mathrm{mg} / \mathrm{I}$ of drinking water. Each replication consisted of 10 broilers. At the end of the research, four broilers from each treatment were cut. The research used the completely randomized design. The variables observed were performance (feed intake, body weight gain and feed conversion), characteristics of the carcass (carcass percentage, meat and bone ratio, and percentage of abdominal fat), and the quality of the meat (fat, cholesterol, and unsaturated fatty acids). Data were analyzed variance analysis. The results showed that feed consumption $(84,80 \mathrm{vs} 89,31 ; 89,16 ; 9163$ $\mathrm{g} / \mathrm{head} /$ day), body weight gain (55,87 vs 59,57; 59,34; 59,70 g/head/day), carcass characteristics, and meat quality were influenced by Phyllanthusniruri extract. Water extracts provide better meat quality than the methanol extract.
\end{abstract}

Keywords : broiler, meat quality, Phyllanthusniruri extract, 


\section{PENDAHULUAN}

Pemeliharaan ayam broiler tidak terlepas dari penggunaan antibiotika, vitamin, vaksin dan obat-obat kimia lain. Penggunaan bahan kimia ini kian hari kian banyak dan dosisnya semakin tinggi sehingga mengakibatkan pengaruh kepada kualitas daging yang dihasilkan. Diantaranya tingginya kadar lemak dalam daging menyebabkan rendahnya kadar protein dan zat gizi lainnya. Konsumen mengaharapkan produksi daging rendah kolesterol, rendah total lipid dan rendah asam lemak jenuh, tetapi kaya asam amino tertentu seperti asam aspartat, asam glutamat dan arginin, rendah tingkat kontaminasi oleh mikrobia patogen dan bebas residu senyawa kimia sintetik serta mengandung protein dan $\beta$ karotin yang tinggi. Permasalahannya adalah bahwa feed additive komersial yang beredar di pasar selain mengandung senyawa kimia sintetik juga tidak mampu memproduksi daging dan telur dengan kriteria tersebut di atas. Feed additive komersial yang dijual di pasar, hanya mengandung sejumlah vitamin, mineral mikro, antioksidan dan antibiotik (Cao et al., 2004).

Untuk mengatasi permasalahan tersebut, maka perlu dicarikan alternatif feed additive alami yang dapat menggantikan feed additive komersial, mampu meningkatkan kekebalan tubuh dan memproduksi daging yang efisien. Feed additive alami tersebut harus mengandung senyawa aktif yang memberikan side effect yang lebih kecil dari pada senyawa kimia sintetik serta berpotensi untuk digunakan sebagai feed additive alami untuk memproduksi daging yang berkualitas. Feed additive alami yang berpotensi untuk menggantikan feed additive komersial antara lain adalah tumbuhan obat. Salah satu tumbuhan obat yang memenuhi kriteria di atas adalah meniran (Phyllanthus niruri L). Meniran diindikasikan mempunyai kemampuan untuk menjaga ketahanan tubuh karena mengandung flavonoid yang mampu meningkatkan kerja sel imun sehingga meningkatkan kekebalan ayam pasca vaksinasi. Disamping itu meniran juga mengandung lignan (filantin, hipofilantin, nirantin, lintetratin), alkaloid, triterpenoid, asam lemak (asam ricinoleat, asam linoleat, asam linolenat), vitamin C, Kalium, damar, tanin dan geranin. Asam lemak esensial (asam richnoleat, asam linoleat dan asam linolenat) berfungsi menurunkan kandungan kolesterol.

Untuk mendapatkan ayam yang sehat guna memproduksi daging dapat diatasi oleh penggunaan ekstrak meniran sebagai pengganti feed additive komersial. Hal ini dikarenakan meniran banyak mengandung senyawa aktif yang dapat berperan sebagai feed additive. Tanaman meniran mengandung senyawa utama yaitu flavonoid (quecertin, quercitrin, isoquercitrin,astragalin, rutin, kaempferol-4, rhamnopynoside), lignan (filantin, hipofilantin, nirantin, lintetratin), alkaloid, triterpenoid, asam lemak (asam ricinoleat, asam linoleat, asam linolenat), vitamin C, Kalium, damar, tanin dan geranin (Bagalkotkar et al., 2006). Flavonoid dari meniran jika dikonsumsi akan bekerja pada sel-sel tubuh yang menjadi bagian dari sistem imun. Caranya dengan mengirimkan sinyal intraseluler pada reseptor sel, sehingga sel bekerja lebih optimal. Filantin dan hipofilantin merupakan komponen utama yang berkhasiat melindungi hati dari zat toksik, baik berupa parasit, virus maupun bakteri (Anonimus, 2006). Terpenoid mampu menghambat bakteri Escherichia coli dan Staphylococcus aureus (Gunawan et al., 2008). Asam lemak linoleat adalah kelompok Omega-6, sedangkan asam lemak linolenat adalah kelompok Omega-3. Kedua asam lemak tersebut tidak dapat disintesis oleh jaringan tubuh, sehingga harus dipasok dari makanan (Murray et al., 1995). Salah satu fungsi Omega-3 adalah menghambat biosintesis kolesterol sehingga keberadaan Omega-3 dalam ransum ayam dapat digunakan untuk melihat sejauh mana penurunan kolesterol dalam daging dan telur.

Astuti (2008) menyatakan bahwa pemberian ekstrak air (infusa) meniran $30 \%$ yang dicampur dalam air minum broiler dapat menekan konsumsi pakan dengan pertambahan bobot badan dan konversi pakan tidak berbeda dengan tanpa pemberian ekstrak air meniran. Hal ini diduga karena kesehatan ayam yang semakin baik sehingga dengan mengkonsumsi pakan yang lebih sedikit dapat mencapai pertambahan bobot badan yang sama dengan tanpa pemberian ekstrak meniran. Sedangkan penelitian Suripta (2008) menyatakan bahwa pemberian ekstrak air meniran dalam air minum sampai $30 \%$ mampu meningkatkan titer antibodi tetapi 


\section{Agrisaintifika \\ Jurnal Ilmu-Ilmu Pertanian \\ Vol. 1, No. 1, 2017}

Astuti, et al. 2017

belum mampu secara nyata meningkatkan jumlah sel limfosit meskipun secara umum jumlah sel limfosit ayam berada di atas normal.

Ekstrak meniran juga mengandung vitamin $\mathrm{C}$ dan vitamin $\mathrm{K}$. Vitamin $\mathrm{C}$ ini telah terbukti merupakan senyawa antistress panas (Ipek et al., 2007). Oleh sebab itu, penggunaan ekstrak meniran berpotensi mengatasi stress panas pada broiler dan ayam petelur yang dipelihara di daerah tropis.

Berdasarkan hasil penelitian dan uraian tersebut di atas, maka diduga bahwa suplementasi ekstrak meniran akan menghasilkan daging dengan mutu lebih baik dan lebih efisien jika dibandingkan dengan feed additive komersial.

\section{BAHAN DAN METODE}

Penelitian ini menggunakan broiler umur satu hari (doc). Pakan yang digunakan adalah BR 1 mengandung protein kasar $20 \%$ dan ME $3200 \mathrm{kkal} / \mathrm{kg}$. Vaksinasi ND dilakukan pada umur 4 hari dengan tetes mata dan umur 21 hari dengan injeksi tembus daging 1 dosis. Sedangkan vaksin gumboro dilakukan pada umur 17 hari.

Broiler sejumlah 200 ekor dikelompokkan ke dalam 4 kelompok perlakuan dan setiap perlakuan terdiri dari 5 buah kandang sebagai ulangan yang berisi 10 ekor. Perlakuan yang diterapkan yaitu sebagai berikut:

1. Kontrol yaitu broiler diberi air minum tanpa mendapatkan feed additive.

2. Kontrol positif yaitu broiler diberi air minum mengandung feed additive komersial (basitrasin)

3. Broiler diberi air minum mengandung 40mg ekstrak meniran yang diekstrak dengan metanol per liter air minum.

4. Broiler diberi air minum mengandung 40mg ekstrak meniran yang diekstrak dengan pelarut air pada suhu $90^{\circ} \mathrm{C}$ per liter air minum.

Broiler dipelihara dalam kandang litter sampai dengan umur 42 hari. Jumlah ransum yang dikonsumsi, konversi pakan dan pertambahan bobot badan diukur setiap minggu. Pada akhir penelitian, 4 ekor broiler umur 42 hari pada setiap kelompok perlakuan dipotong dan lemak perut, karkas dan bagiannya ditimbang.

Uji kualitas daging meliputi uji meatbone ratio, dan cooking loss. Meat-bone ratio diperoleh dengan cara bobot daging dibagi dengan tulang dikali seratus persen. Cooking loss diperoleh dengan cara mengukus daging bagian dada pada suhu $80^{\circ} \mathrm{C}$ selama 20 menit dan kemudian didinginkan selama 30 menit. Cooking loss dihitung dengan rumus sebagai berikut:

$$
\frac{\text { Berangelum-satah dihwh }}{\text { Eerat gelelum dihüus }} \times 100 \%
$$

Analisis kandungan kolesterol dan asam lemak dilakukan di Laboratorium pangan dan Gizi PAU UGM.Hasil penelitian dianalisis dengan ANOVA dan jika berbeda nyata diuji lanjut dengan Duncan's Multiple Range Test.

\section{HASIL DAN PEMBAHASAN}

\subsection{Performans ayam broiler}

Hasil penelitian penggunaan ekstrak meniran terhadap performans ayam broiler dapat dilihat pada Tabel 1. (Lampiran)

Hasil analisis ragam menunjukkan bahwa konsumsi pakan ayam broiler yang mendapatkan perlakuan ekstrak meniran baik ekstrak metanol maupun ekstrak air lebih tinggi dan berbeda nyata $(P<0,05)$ dibandingkan dengan kontrol tanpa ekstrak meniran, namun tidak berbeda dari pemberian basitrasin. Hal ini menunjukkan bahwa pemberian feed additive meniran dalam air minum mampu meningkatkan konsumsi pakan. Pemberian meniran akan meningkatkan kesehatan tubuh. Ayam yang sehat maka dimungkinkan mengkonsumsi pakan lebih banyak. Konsumsi pakan rata-rata pada penelitian ini berkisar antara 84,8 gram/ekor/hari sampai 91,63 gram/ekor/hari. Konsumsi pakan ini lebih rendah dari penelitian Herlina et al., (2015) yaitu sebesar 98,12 gram/ekor/hari. Hal ini dikarenakan ayam semakin sehat dan daya tahan tubuh semakin baik sehingga konsumsinya semakin tinggi. Tillman et al. (1991) menjelaskan konsumsi ransum digunakan untuk proses pertumbuhan, aktivitas dan mempertahankan suhu tubuh.

Hasil analisis ragam pertambahan bobot badan ayam yang mendapatkan feed additive 
berbeda nyata $(P>0.05)$ dibandingkan tanpa feed additive. Perbedaan pertambahan bobot badan ini erat kaitannya Dengan lebih tingginya konsumsi pakan dan kemungkinan karena peningkatan daya tahan tubuh atau kesehatan tubuh yang semakin baik akibat pemberian meniran. Faktor yang mempengaruhi bobot badan ayam broiler antara lain; genetik, jenis kelamin, konsumsi pakan, suhu, manajemen perkandangan dan sanitasi. Disamping itu kemungkinan dipengaruhi adanya kandungan vitamin C dalam meniran. Menurut Ipek et al. (2007) pemberian vitamin C mampu meningkatkan produksi telur, efisiensi penggunaan pakan dan pertambahan berat badan.

Hasil analisis ragam terhadap konversi pakan menunjukkan bahwa tidak terdapat yang perbedaan yang nyata $(P>0,05)$ antara ayam diberi ekstrak meniran maupun kontrol. Hal ini menunjukkan bahwa penambahan ekstrak meniran memiliki efisiensi pakan yang sama Dengan ayam yang kontrol. Konversi pakan pada penelitian ini berkisar antara 1,51sampai 1,61. Konversi ini lebih rendah dari hasil penelitian Siswanto (2010) yaitu 1,71.

\subsection{Karakteristik Karkas}

Karakteristik karkas yang diamati adalah persentase karkas, rasio daging tulang, dan persentase lemak abdominal, dapat dilihat pada Tabel 2.Persentase karkas (potongan tanpa darah, bulu, kepala, leher, kaki dan isi perut) umumnya berkisar antara $65-75 \%$. Rata-rata persentase karkas ayam broiler yang diberi ekstrak meniran lebih tinggi dibanding kontrol, Perlakuan ekstrak air tidak berbeda dengan ekstrak meniran dan basitrasin. Pemberian ekstrak meniran menyebabkan bobot badan meningkat, sehingga akan berpengaruh pada karkas. Karkas merupakan hasil utama pemotongan ternak yang memiliki nilai ekonomis tinggi (Soeparno, 1994).

Haroen (2003) menjelaskan pencapaian bobot karkas sangat berkaitan dengan bobot potong dan pertambahan bobot badan. Karkas yang baik memiliki banyak jaringan otot dan sedikit mungkin jaringan lemak. Menurut Kartasudjana dan Suprijatna (2005), faktorfaktor yang mempengaruhi persentase karkas adalah konformasi tubuh dan derajat
kegemukan.Ternak yang gemuk, persentase karkasnya tinggi dan umumnya berbentuk tebal seperti balok.

Hasil analisis ragam terhadap rasio daging tulang (Meat Bone Ratio (MBR)) ayam broiler menunjukkan bahwa terdapat perbedaan yang nyata $(P<0,05)$ antara ayam diberi ekstrak meniran Dengan control tanpa pemberian feed additive maupun Dengan basitrasin. Hal ini menunjukkan bahwa penambahan ekstrak meniran mempengaruhi Meat Bone Ratio. Namun tidak ada perbedaan MBR antara ekstrak air dan methanol. Hasil penelitian Hidajati (2005) menyebutkan bahwa rasio daging tulang ayam broiler tanpa perlakuan sebesar 3,73 . Hasil penelitian ini lebih rendah disbanding penelitian Hidajati (2005).

Hasil analisis ragam terhadap persentase lemak abdominal ayam broiler menunjukkan bahwa terdapat perbedaan yang nyata $(P<0,05)$ antara ayam diberi ekstrak meniran maupun kontrol. Persentase lemak abdominal pada ayam yang diberi ekstrak meniran lebih tinggi disbanding control tanpa feed additive, namun lebih rendah disbanding control basitrasin. Hal ini menunjukkan bahwa penambahan ekstrak meniran mempengaruhi persentase lemak abdominal. Menurut Amrullah (2006) bobot karkas berbeda-beda untuk setiap umurnya seperti pada umur 8 minggu memiliki bobot karkas sekitar 1,995 gram dengan persentase bagian-bagian karkas yaitu lemak abdominal $4,3 \%$, sayap $9,6 \%$, betis $13,0 \%$, paha $16,6 \%$, dada bertulang $34,2 \%$ dan dada tanpa tulang 22,6\%. Dengan demikian ayam broiler pada penelitian inimemilik ikandungan lemak abdominal yang lebih rendah dibanding Amrullah (2002).

\subsection{Kualitas Daging}

\section{Persentase Lemak Daging}

Hasil analisis persentase lemak daging paha terdapat pada Tabel 3. Rata-rata persentase persentase lemak daging ayam broiler berkisar antara 5,74 sampai dengan 6,49 . Hasil analisis ragam menunjukkan bahwa tidak terdapat perbedaan yang nyata $(P>0,05)$ antar perlakuan. Hal ini berarti persentase lemak daging paha tidak dipengaruhi oleh ekstrak meniran.. Pada penelitian ini terdapat 
Astuti, et al. 2017

kecenderungan kandungan lemak daging yang diberi ekstrak air semakin menurun dibanding pemberian ekstrak methanol.

Havenstein et al., (2005) menjelaskan bahwa lemak dalam ayam pedaging (umur 43 hari) sekitar $10-15 \%$ dari total bobot karkas. Hasil penelitian Mulyati (2003) menyebutkan bahwa kadar lemak daging sebesar $4,6 \%$ pada ayam yang diberi ransum Dengan inokulasi ragi oncom dan 5,5\% untuk ayam yang diberi ransum Dengan inokulasi ragi tempe. Hasil penelitian ini lebih tinggi kadar lemaknya.

Lemak daging merupakan lemak yang berada dibagian tubuh (karkas) yang sangat menentukan dalam kualitas dari ayam pedaging. Semakin besar persentase lemak daging, maka semakin menurun kualitas daging ayam pedaging tersebut sebab konsumen menghendaki kadar lemak dalam daging yang rendah.

\section{Kolesterol daging}

Hasil analisis ragam terhadap kolesterol daging paha ayam broiler menunjukkan adanya perbedaan yang nyata $(P<0,05)$ antar perlakuan. Perlakuan pemberian ekstrak air lebih rendah kandungan kolesterolnya disbanding pemberian ekstrak methanol, basitrasin, dan control tanpa pemberian feed additive. Kandungan kolesterol daging ayam pada penelitian lebih rendah disbanding hasil penelitian Siswanto (2010) yang menyebutkan bahwa kandungan kolesterol daging ayam adalah 3,03 mg/gram daging. Sedangkan Rusmanaet al (2010) menyatakan kandungan kolesterol broiler mencapai $79 \mathrm{mg} / 100 \mathrm{~g}$ bobot badan. Menurut Chan et al. (1995) dikutip Rusmana et al., (2010), kadar kolesterol daging ayam broiler adalah 100 mg/100gram dan menurut Forest (1987) yang dikutip Rusmana et al., (2010) adalah $110 \mathrm{mg} / 100 \mathrm{~g}$. Keberadaan lemak pada bahan pangan hampir selalu dikuti senyawa sterol yang disebut kolesterol sehingga pengurangan jumlah lemak di dalam bahan juga akan menurunkan jumlah kolesterol bahan tersebut. Hasil penelitian ini tidak sesuai dengan pernyataan di atas, kandungan lemak tidak berbeda nyata, namun kandungan kolesterolnya menurun dengan adanya penambahan ekstrak meniran. Dilihat dari jenis ekstrak meniran, ekstrak air lebih rendah kandungan kolesterolnya dibanding ekstrak meniran.

\section{Kandungan Asam lemak Daging}

Hasil analisis ragam terhadap kandungan asam lemak tak jenuh daging paha ayam broiler menunjukkan adanya perbedaan yang nyata $(P<0,05)$ antar perlakuan. Hal ini menunjukkan bahwa ekstrak meniran mempengaruhi kadar asam lemak daging. Kandungan asam lemak tak jenuh pada perlakuan ekstrak methanol dan basitrasin lebih rendah dibandingkan perlakuan ekstrak air dan control tanpa feed additive. Dengan kata lain, ekstrak air dapat meningkatkan kadar asam lemak tak jenuh. Kandungan asam oleat paling tinggi diantara kandungan yang lain dan semakin meningkat Dengan penambahan ekstrak meniran, namun lebih rendah dibandingkan penelitian Harjanto (2006). Menurut Harjanto (2006) . kandungan asam oleat pada daging ayam paling besar, diantara asam lemak lainnya (62,764-68,541 g/l00g). Sedang EPA pada ayam berkisar $(0,163-0,830$ $\mathrm{g} / 100 \mathrm{~g})$, dan DHA berkisar $(0,074-0,343$ $\mathrm{g} / 100 \mathrm{~g})$. Hasil penelitian ini tidak terdeteksi kandungan EPA di semua perlakuan, sedangkan kandungan DHA hanya terlihat pada perlakuan kontrol dan ekstrak methanol.

\section{KESIMPULAN}

Penggunaan ekstrak meniran dalam air minum ayam broiler mampu menggantikan antibiotic basitrasin dan dapat meningkatkan performans (konsumsi pakan dan bobot badan), karakteristik karkas (persentase karkas, rasio daging tulang, dan persentase lemak abdominal), dan kualitas daging (menurunkan kolesterol dan meningkatkan asam lemak tak jenuh) ayam broiler. 
Astuti, et al. 2017

Tabel 1. Konsumsi Pakan, Pertambahan Bobot Badan, dan Konversi Pakan Ayam Broiler Yang Mendapatkan Ekstrak Meniran.

\begin{tabular}{lccc}
\hline \hline Perlakuan & $\begin{array}{c}\text { Konsumi Pakan } \\
\text { (g/ek/hr) }\end{array}$ & $\begin{array}{l}\text { Pertambahan } \\
\text { Bobot Badan } \\
\text { Harian }(\mathrm{g} / \mathrm{ek} / \mathrm{hr})\end{array}$ & $\begin{array}{c}\text { Konversi } \\
\text { Pakan }\end{array}$ \\
\hline K0 (kontrol) & $84,80^{\mathrm{a}}$ & $55,87^{\mathrm{a}}$ & 1,52 \\
K1 (basitrasin) & $89,31^{\mathrm{b}}$ & $59,57^{\mathrm{b}}$ & 1,50 \\
K2 (metanol) & $89,16^{\mathrm{b}}$ & $59,34^{\mathrm{b}}$ & 1,53 \\
K3 (air) & $91,63^{\mathrm{b}}$ & $59,70^{\mathrm{b}}$ & 1,54 \\
\hline \hline
\end{tabular}

Ket : superskrip yang berbeda pada kolom yang sama menunjukkan beda nyata $(P<0,05)$

Tabel 2. Karakteristik Karkas Ayam Broiler yang Mendapatkan Ekstrak Meniran

\begin{tabular}{lccc}
\hline \hline Perlakuan & $\begin{array}{c}\text { Persentase } \\
\text { karkas }\end{array}$ & $\begin{array}{c}\text { Rasio daging } \\
\text { tulang }\end{array}$ & $\begin{array}{c}\text { Persentase } \\
\text { Lemak } \\
\text { Abdominal }\end{array}$ \\
\hline K0 (kontrol) & $65,70^{\mathrm{a}}$ & $2,96^{\mathrm{a}}$ & $1,58^{\mathrm{a}}$ \\
K1 (basitrasin) & $66,72^{\mathrm{ab}}$ & $2,95^{\mathrm{a}}$ & $2,28^{\mathrm{c}}$ \\
K2 (metanol) & $69,19^{\mathrm{b}}$ & $3,54^{\mathrm{b}}$ & $1,86^{\mathrm{b}}$ \\
K3 (air) & $69,36^{\mathrm{b}}$ & $3,43^{\mathrm{b}}$ & $1,61^{\mathrm{ab}}$ \\
\hline \hline
\end{tabular}

Ket : superskrip yang berbeda pada kolom yang sama menunjukkan beda nyata $(P<0,05)$

Tabel 3. Persentase lemak, kandungan kolesterol, dan asam lemak tak jenuh daging ayam broiler yang mendapatkan ekstrak meniran

\begin{tabular}{lccc}
\hline \hline Perlakuan & $\begin{array}{c}\text { Persentase } \\
\text { lemak daging }\end{array}$ & $\begin{array}{c}\text { Kandungan } \\
\text { kolesterol } \\
(\mathrm{mg} / 100 \mathrm{~g})\end{array}$ & $\begin{array}{c}\text { Asam lemak } \\
\text { tak jenuh }\end{array}$ \\
\hline K0 (kontrol) & 5,74 & $7.56^{\mathrm{b}}$ & $59,19^{\mathrm{a}}$ \\
K1 (basitrasin) & 6,39 & $8.52^{\mathrm{b}}$ & $54,39^{\mathrm{b}}$ \\
K2 (metanol) & 6,49 & $8.67^{\mathrm{b}}$ & $53,77^{\mathrm{b}}$ \\
K3 (air) & 5,89 & $5.95^{\mathrm{a}}$ & $59,31^{\mathrm{a}}$ \\
\hline \hline
\end{tabular}

Ket : superskrip yang berbeda pada kolom yang sama menunjukkan beda nyata $(\mathrm{P}<0,05)$

\section{DAFTAR PUSTAKA}

Amrullah, I.K. 2006. Nutrisi Ayam Broiler. Lembaga Satu Gunung Budi. Bogor

Anonimus, 2006. Ekstrak Meniran Optimalkan Kekebalan. http://www.suaramerdeka.com/harian/ 0605/01/ragam01.htm

Astuti, P., 2008. Pengaruh Ekstrak Meniran (Phyllanthus niruri L) Terhadap Performan Produksi Ayam Broiler.
Majalah IImiah Dian Andhini Vol 13 No. 1 Maret 2008

Bagalkotkar G, Sangidu SR, Saad MS, and Stansals J, 2006. Phytochemicals from Phyllanthus niruri Linn. and Their Pharmacological Properties: A Review, Journal of Pharmacy and Pharmacology, 2006, 58 (12),155970. 
Cao, J., K. Li, X. Lu and Y. Zhao. 2004. Effects of florfenical and chromium (III) on humoral immune response in chicks. Asian-Aust. J. Anim. Sci. 17: 366-370.

Gunawan, I.W.G., I.G.A. Gede Bawa dan N.L. Sutrisnayanti, 2008. Isolasi dan Identifikasi Senyawa Terpenoid Yang Aktif Antibakteri pada Herba Meniran (Phyllanthus niruri Linn). Jurnal Kimia 2 (1), Januari 2008 : 31-39

Haroen, U. 2003. Respon Ayam Broiler yang Diberi Tepung Daun Sengon (Albizzia falcataria) dalam Ransum terhadap Pertumbuhan dan Hasil Karkas. J. IImiah IImu-ilmu Peternakan. 6 (1): 3441.

Harjanto, D. 2006. Kualitas Kimia Daging Dada Ayam Broiler Yang Pakannya Ditambahkan Campuran Minyak Ikan Kaya Asam Lemak Omega-3. Skripsi. Fakultas Paeternakan. IPB. Bogor

Havenstein, G. B., P. R. Ferket and M. A.Qureshi. 2005. Growth, livability andfeed conversion of 1957 versus 2001 broilers when fed representative 1957 and 2001 broiler diets. Poult. Sci. 82: 1500-1508

Herlina, B., R. Novita dan T. Karyono. 2015. Pengaruh Jenis dan Waktu Pemberian Ransum terhadap Performans Pertumbuhan dan Produksi Ayam Broiler. Jurnal Sain Peternakan Indonesia Vol. 10 No 2 Juli-Desember 2015

Hidajati, Nove . 2005. Peran Bawang Putih (Allium sativum) dalam Meningkatkan Kualitas Daging Ayam Pedaging. Media Kedokteran Hewan Vol. 21, No. 1, Januari 2005

Ipek, A., O. Canbolat dan A. Karabulut. 2007. The effect of vitamin $E$ and vitamin $C$ on the performance of japanese quails (Coturnixcoturnix Japonica) reared under heat stress during growth and egg production period.
Asian-Aust. J. Anim. Sci. 20:252256.

Kartasudjana, R. dan E. Suprijatna. 2005. Manajemen Ternak Unggas. Penebar Swadaya, Jakarta.

Mulyati, 2003. Pengaruh Penggunaan Bungkil Biji Karet Yang Difermentasi dengan Ragi Tempe dan Oncom Dalam Ransum Terhadap Kualitas Daging Ayam Broiler.Tesis. Program Studi Magister IImu Ternak. Program Pasca Sarjana Fakultas Peternakan Universitas Diponegoro. Semarang.

Murray, R.K., D.K. Granner, P.A. Mayes and V.W. Rodwell. 1995. Biokimia Harper. ECG. Jakarta.

Rusmana, Denny, D. Natawiharja, dan Happali . 2010. Pengaruh Pemberian Ransum Mengandung Minyak Ikan Lemuru Dan Vitamin E Terhadap KadarLemak Dan Kolesterol Daging Ayam Broiler. Pustaka.unpad.ac.id.

Siswanto, 2010. Kadar Kolesterol Pada Beberapa Bagian Tubuh Ayam Potong Jantan Yang Diberi Formula Pakan Dengan Dedak Padi Konsentrasi Tinggi. Buletin Veteriner Udayana Vol 2 No. 1 Februari 2010.

Soeparno. 1994. Ilmu dan Teknologi Daging. Fakultas Peternakan. Universitas Gadjah Mada. Gadjah Mada University Press. Yogyakarta

Suripta, H. 2008. Pengaruh Pemberian Ekstrak Meniran (Phyllanthus niruri L) Terhadap Respon Kekebalan Ayam Broiler Pasca Vaksinasi ND. Majalah Ilmiah Dian Andhini : 861-868

Tillman, A.D., Hartadi, H., Reksohadiprodjo,S.,Prawirokusumo, S., dan Lebdoseokojo, S., 1991. IImu Makanan Ternak Dasar. Gadjah Mada University Press. Yogyakarta. 